\title{
Exchange Rate Volatility And Foreign Direct Investment: Evidence From East Asian Countries
}

\author{
Dharmendra Dhakal, Tennessee State University, USA \\ Raja Nag, New York Institute of Technology, USA \\ Gyan Pradhan, Eastern Kentucky University, USA \\ Kamal P. Upadhyaya, University of New Haven, USA
}

\begin{abstract}
This paper uses panel data to examine the effect of exchange rate uncertainty on foreign direct investment in China, Indonesia, Malaysia, the Philippines, South Korea, and Thailand - countries that have continued to attract considerable foreign direct investment (FDI) inflows while also experiencing a great deal of volatility in exchange rates. After establishing the stationarity of the data series, a panel cointegration test was conducted, following which an error correction model was developed and estimated using two sets of panel data. The overall estimation results are consistent with theoretical predictions. We find that exchange rate volatility has a favorable effect on foreign direct investment in our sample countries.
\end{abstract}

Keywords: Exchange rate uncertainty, FDI, GARCH, unit root, co-integration

\section{INTRODUCTION}

$\mathscr{M}$ acroeconomic variables, such as GDP, the inflation rate, and the real exchange rate, exhibit extreme volatility in developing countries (Easterly, Islam and Stiglitz, 2000). The excess volatility of these variables affects not only the volume and level of international trade, but also the level of private investment and the flow of the foreign direct investment. There are several studies that explore the relationship between exchange rate uncertainty that is associated with exchange rate volatility on private investment (Pradhan $e t$ al, 2004; Bhandari and Upadhyaya, 2008). There is, however, a dearth of literature exploring the relationship between foreign direct investment and exchange rate uncertainty. In this paper, we extend the literature on the exchange rate uncertainty and investment relationship further by exploring the effect of exchange rate uncertainty on foreign direct investment (FDI) in several East Asian countries. We believe this investigation is appropriate and timely, given the large inflows of FDI in China in recent years and the fact that other East Asian countries, such as Indonesia, Malaysia, the Philippines, South Korea, and Thailand, have continued to attract considerable FDI inflows. Moreover, the exchange rates of these countries (except China) have experienced a great deal of variability - depreciating against the dollar in the nineties and appreciating against the dollar in recent years. We hope that our study using recent data from these East Asian countries will provide a better understanding of the exchange rate uncertainty and FDI relationship.

The organization of the paper is as follows. Section II reviews some of the literature related to the exchange rate uncertainty, investment and FDI relationship. Section III presents the theoretical background. Section IV discusses the methodology and data. In section V, we present the estimation and empirical results. Finally, section VI summarizes and concludes the paper.

\section{BRIEF REVIEW OF LITERATURE}

As indicated earlier, macroeconomic variables exhibit extreme volatility, particularly in developing countries. The excess volatility of these variables affects international trade as well as domestic investment and 
FDI. Some recent studies attempt to identify the theoretical links and the channels through which uncertainty affects investment (Caballero, 1991; Abel and Eberly, 1994). By and large, these studies are inconclusive. Under different assumptions, uncertainty tends to affect investment in different ways. In addition, the magnitude of the effect depends on a variety of other factors. Therefore, from a theoretical perspective, the precise relationship between uncertainty and investment remains uncertain.

There are several competing theories that attempt to explain the impact of uncertainty on private investment. One set of arguments (Hartman, 1972; Abel, 1983) suggests that higher price-uncertainty raises the expected profitability of capital, increases the desired capital stock and ultimately increases the level of investment. This argument is based on the assumption of risk neutral investors under which the relationship between the expected marginal revenue product of capital and uncertain variables such as prices and output demand shape the effect of uncertainty on investment (Serven, 2003). Since most investment projects are irreversible in nature, Dixit and Pindyck (1994) argue that investment adjustment costs are asymmetric - they are larger for downward than for upward adjustment. Under such conditions, due to the risk of getting stuck with too much capital if events turn unfavorable, an investment decision is made only when the difference between the expected profitability and the cost of capital exceeds a certain threshold (Serven, 2003). Bernanke (1983), however, suggests that even if uncertainty may raise the profitability of all investment projects, it makes their relative ranking uncertain. Under such a situation, the investors try to avoid their irreversible investment mistakes in wrong projects which may depress aggregate investment. If it is assumed that investors are risk averse as opposed to risk neutral then the overall effect of uncertainty on investment may be negative (Zeira, 1990). Lee and Shin (2000) argue that investment uncertainty may raise the level of investment only when the output share of the variable input is larger.

In recent years, many researchers have examined the relationship between real exchange rate uncertainty and the level of aggregate investment in the economy. For example, Goldberg (1993) studies the impact of the exchange rate and its uncertainty on industry-level investment in the United States and finds that in the 1980s the real dollar depreciation (appreciation) was likely associated with investment contraction (expansion). Darby et al. (1999) examine real exchange rate uncertainty and aggregate investment for five OECD countries and finds mixed results in the sense that there were circumstances in which rising volatility would increase or decrease investment.

A couple of more recent studies on the effect of uncertainty on the level of private investment are by Serven (2003) and Pradhan, et al. (2004). Serven's study is based on cross-country time series data for 61 countries for the 1970-1995 period and finds a strong negative effect of real exchange rate uncertainty on private investment. He finds the effect particularly large in relatively open economies. Pradhan, et al. (2004) examine the effect of real exchange rate uncertainty on aggregate private investment in Indonesia, Malaysia, the Philippines and Thailand using time series data from 1972-2000. After analyzing the time series properties of the data they estimate an error correction model for each of these countries. They find different results for different countries.

There are a few studies that explore the relationship between exchange rate uncertainty and FDI. For example Cushman, $(1985,1988)$ in his studies of exchange rate risk (due to exchange rate volatility) finds a negative relationship between FDI flows from the United States and exchange rate risk. Goldberg and Kolstad (1995), however, argue that if both the real demand and exchange rate shocks are assumed, exchange rate volatility tends to increase the FDI share even with identical costs of production across countries. In their empirical work using quarterly U. S. bilateral FDI flows to four countries from 1978-1991, they show that exchange rate volatility and the share of FDI in total investment are positively related. This finding supports their theoretical prediction that investors are risk averse. They also find that a depreciation of the source country currency leads to a reduction in FDI outflows but this effect is not very large.

Sung and Lapan (2000) use the irreversibility literature in an open economy by Dixit and Pindyck (1994) and Abel (1983) to explore the impact of exchange rate uncertainty on FDI of a risk neutral multinational firm (MNF) which may open a plant at home or abroad. They show that it can be profitable for the MNFs to open plants in two different countries with sufficient exchange rate volatility, essentially implying that FDI increases with exchange rate volatility. Roy and Viaene (1998) develop a model in which FDI is motivated by strategic considerations. Their model incorporates intermediate inputs that are produced abroad in an oligopolistic market. This allows FDI firms to bid up the price of inputs to non-foreign investing competitors which increases the 
opportunity cost of non-investment and leads to bunching of FDI. Under such circumstances, exchange rate variability has a positive effect on FDI.

\section{THEORETICAL BACKGROUND}

There are a number of factors that attract foreign direct investment (FDI) in a country. An important one among them is the market size of the host country. The market size hypothesis suggests that investment will go primarily to markets large enough to support the scale economies needed for production. This reasoning has been pervasive given that most investment has been market seeking, and it helps to explain why most FDI goes to developed countries rather than to emerging economies (Ajami and BarNiv, 1984). However, evidence from studies comparing FDI flows to different emerging economies has been mixed. On the one hand, Root and Ahmed (1979) and Tuman and Emmert (1999) use gross domestic product as a proxy for market size and find it to be insignificant in explaining FDI in Latin American countries. On the other hand, Daniels and Quigley (1980) find that gross domestic product was not only significant but was the most important variable in explaining FDI inflows among Latin American countries.

The current account balance of the host country can be viewed an indicator of the strength of its currency. A deteriorating current account balance is likely to lead to a depreciation of the host country's currency. It is possible that potential multinational investors view current account deficits negatively because such deficits may lead to inflation and exchange rate variations. If this is the case, then an increase in the current account deficit may lead to a reduction in FDI inflows. In contrast, if multinational companies take advantage of the current account deficits of the host country by negotiating more favorable operative terms, then the current account deficits may increase FDI inflows.

Foreign investors may gain or lose from a depreciating exchange rate. For instance, a depreciating exchange rate may boost exports and provide gains from resource-seeking FDI. Foreign investors, however, may lose as well because they must incur costs to prevent transaction and translation losses when currencies depreciate. If they believe that depreciation will continue after they enter a country, they may conclude that the costs will be too high to justify their investments. In fact, Grosse and Trevino (1996), Froot and Stein (1991), Klein and Rosengren (1994), and Tuman and Emmert (1999) find mixed investor reactions to exchange rate depreciation. Leiderman and Thorne (1996) report that FDI into Mexico changed very little after the Mexican currency crisis and devaluation of 1994. Further, in spite of the high value of the U.S. dollar during much of the 1980s, the United States was a net recipient of FDI. Therefore, the impact of exchange rate depreciation on FDI inflows seems to be ambiguous. As discussed in the previous section, exchange rate risk that is created by exchange rate volatility also affects the flow of FDI; various studies have pointed to scenarios where the impact may be negative as well as positive.

The relationship between international trade and FDI is also not entirely clear. On the one hand, protectionist policies in the host country encourage FDI. Conversely, firms' ability to successfully export may justify their making more permanent investment in that country. Nevertheless, many countries have imposed import substitution policies to successfully attract FDI, a fact that helps to explain why most FDI historically has been market seeking rather than resource seeking. Under this scenario, one would expect a country's high import restrictions and low levels of trade to correlate with high FDI.

The case of East Asian countries, however, is different. These countries have historically been relatively open to trade and investment. Transnational corporations (TNCs) look for more trade and more open economies for resource-seeking operations, especially as they integrate their global production with vertical and horizontal valuechain linkages. For a country to be a part of this integration process, it must allow TNCs to easily import and export. This integration is particularly important when TNCs seek a base to serve regional markets (Chudnovsky, Lopez and Porta, 1995). In order to capture this phenomenon, our model includes openness of the host country as a determinant of FDI inflows, and it is expected that this variable will be positively associated with FDI inflows. 


\section{METHODOLOGY AND DATA}

In order to analyze the impact of the different variables on FDI inflows discussed above, the following model is developed:

$F D I_{i t}=b_{0}+b_{1} C A B_{i t}+b_{2} O P E N_{i t}+b_{3} Y_{i t}+b_{4} R E R_{i t}+b_{5} R E R V O L_{i t}+e_{i t}$

Where

$F D I_{i t}=$ foreign direct investment inflow in country $i$ in time $t$

$C A B_{i t}=$ current account balance in country $i$ in time $t$

$O P E N_{i t}=$ openness (sum of export and import divided by GDP) in country $i$ in time $t$

$R E R_{i t}=$ real exchange rate with U.S. dollar of country $i$ in time $t$ defined as the nominal exchange rate times the foreign price (U.S. CPI) divided by domestic price (domestic CPI)

$R E R V O L_{i t}=$ real exchange rate uncertainty in country $i$ in time $t$

$e=$ random error term.

As discussed above, the signs for $b_{1}$ and $b_{2}$ are expected to be positive while those for $b_{3}$ and $b_{4}$ are uncertain. The main focus of our study is the coefficient of RERVOL $\left(b_{5}\right)$. A GARCH $(1,1)$ specification with an equation in which its own lag and foreign to domestic price ratios is estimated and the conditional variance derived from this estimation is used as a measure of real exchange rate uncertainty (RERVOL). If the coefficient of RERVOL is positive and statistically significant then we could argue that exchange rate uncertainty positively affects FDI inflows in the host country. If the coefficient is negative and statistically significant, FDI negatively affects FDI inflows. An insignificant coefficient would imply that there is no effect.

For our study, annual time series data from China (1982-2005), Indonesia (1981-2005), Malaysia (19742005), the Philippines (1977-2005), South Korea (1976-2005) and Thailand (1975-2005) are collected and a panel data set is constructed. All the data have been obtained from World Development Indicators CD-ROM 2007.

\section{ESTIMATION AND EMPIRICAL RESULTS}

As indicated above, this study uses panel data that from China, Indonesia, Malaysia, the Philippines, South Korea and Thailand. Since the use of non-stationary data can produce erroneous results, it is important to test for the stationarity of the data series. To ensure the stationarity of the panel data, Levin, et al. (2002), Breitung (2000), and Im, et al. (2003) tests are carried out. The data are found to be stationary at the first difference level. The test results are reported in Table 1.

After establishing the stationarity of the data series, a panel cointegration test (Pedroni 1999, 2004) was conducted. The test results are reported in Table 2. The test results suggest that the null hypothesis of no cointegration is rejected. Therefore, following Engle and Granger (1987), an error correction model is developed as follows:

$\triangle F D I_{i t}=c_{0}+c_{1} \Delta C A B_{i t}+c_{2} \Delta O P E N_{i t}+c_{3} \Delta Y_{i t}+c_{4} \Delta R E R_{i t}+c_{5} \Delta R E R V O L_{i t}+c_{6} E C_{i t}+v_{i t}$

In Equation 2, EC is the error correction term and is the lag of the estimated error term of Equation 1. The coefficient of the error term is expected to be negative. Since we are using panel data, the model is estimated using a fixed-effects estimator. The estimated results are reported in Table 3.

We estimate Equation 2 using two sets of panel data. First, we estimate the model using all the panel data which is reported in column 1. Since our sample includes four countries that belong to ASEAN, we also estimate the model using a panel data from these countries. The estimated results are reported in column 2. As seen in Table 3 , the overall estimation results are consistent with theoretical predictions. However, the coefficients of openness and the current account balance are not statistically significant. The coefficient of market size that is represented by real GDP is positive and statistically significant, as expected. Indeed, China and other East Asian countries included 
in the sample probably represent one of the largest markets for manufacturing goods that attract market seeking FDI. The coefficient of the real exchange carries a negative and significant sign in both of the estimation presumably due to translation and transaction costs which discourage FDI.

The main focus of our study is the exchange uncertainty that arises because of exchange rate volatility (RERVOL). The coefficient of RERVOL is positive at the 10 percent critical level in the full sample as well as in the ASEAN data. Given the historical depreciation of exchange rates of most East Asian countries (with the exception of China) it is possible that MNCs perceive volatility more towards the depreciation. As discussed above, under such circumstances, it can be profitable to move production to these countries.

\section{SUMMARY AND CONCLUSION}

This paper uses panel data to examine the effect of exchange rate uncertainty on foreign direct investment in China, Indonesia, Malaysia, the Philippines, South Korea, and Thailand - countries that have continued to attract considerable FDI inflows, while also experiencing a great deal of volatility in exchange rates. After establishing the stationarity of the data series, a panel cointegration test is conducted, following which an error correction model is developed and estimated using two sets of panel data. The overall estimation results are consistent with theoretical predictions. We find that exchange rate volatility has a favorable effect on foreign direct investment in our sample countries.

Table 1: Panel Unit Root Test

\begin{tabular}{|c|c|c|c|c|c|c|}
\hline \multirow{2}{*}{ Variable } & \multicolumn{2}{|c|}{ LLC Test } & \multicolumn{2}{|c|}{ Breitung Test } & \multicolumn{2}{|c|}{ IPS Test } \\
\hline & Level & FD & Level & FD & Level & FD \\
\hline FDI & -1.10 & $-4.46 * * *$ & $-3.46 * * *$ & $-6.16 * * *$ & -0.90 & $-3.32 * * *$ \\
\hline $\mathrm{CAB}$ & -0.47 & $-5.13 * * *$ & -1.47 & $-4.07 * * *$ & 0.15 & $-5.08 * * *$ \\
\hline RER & -0.96 & $-5.11 * * *$ & -1.71 & $-5.82 * * *$ & -1.03 & $-5.30 * * *$ \\
\hline RERVOL & 0.23 & $-6.86 * * *$ & -1.47 & $-6.79 * * *$ & -0.44 & $-6.58 * * *$ \\
\hline OPEN & 0.75 & $-4.25 * * *$ & -0.05 & $-5.67 * * *$ & -0.31 & $-4.31 * * *$ \\
\hline $\mathrm{Y}$ & 1.70 & $-3.91 * * *$ & 3.77 & $-1.82 *$ & 0.76 & $-3.87 * * *$ \\
\hline $\begin{array}{l}\text { LLC: Levir } \\
\text { IPS: Im, Pe } \\
\text { ***: signifi } \\
\text { **: signific } \\
\text { *: significa }\end{array}$ & $\begin{array}{l}\text { hu Test } \\
\text { hin Test } \\
\text { critical le } \\
\text { itical les } \\
\text { itical les }\end{array}$ & & & & & \\
\hline
\end{tabular}

Table 2: Pedroni Residual Cointegration Test

\begin{tabular}{|l|c|c|}
\hline Test & Test Statistics & Probability \\
\hline Panel v-stat & -1.86 & 0.071 \\
\hline Panel rho-stat & 3.29 & 0.001 \\
\hline Panel PP-stat & 3.11 & 0.003 \\
\hline Panel ADF-test & 8.33 & 0.000 \\
\hline Group rho-stat & 3.151 & 0.003 \\
\hline Group PP-stat & 1.678 & 0.098 \\
\hline Group ADF-stat & -0.404 & 0.368 \\
\hline
\end{tabular}




\begin{tabular}{|c|c|c|}
\hline \multicolumn{3}{|c|}{$\begin{array}{c}\text { Table 3: Estimation of Equation } 2 \\
\text { Dependent Variable } \Delta \text { FDI }\end{array}$} \\
\hline \multirow{2}{*}{ Variable } & \multicolumn{2}{|c|}{ Estimated Coefficient } \\
\hline & Column 1 & Column 2 \\
\hline Constant & $\begin{array}{l}71.215 \\
(0.250)\end{array}$ & $\begin{array}{c}512.04 \\
(2.04)^{* *}\end{array}$ \\
\hline$\triangle \mathrm{CAB}$ & $\begin{array}{c}0.007 \\
(0.253)\end{array}$ & $\begin{array}{l}-0.012 \\
(1.056)\end{array}$ \\
\hline$\triangle \mathrm{RER}$ & $\begin{array}{c}-0.760 \\
(3.130)^{* * *}\end{array}$ & $\begin{array}{c}-0.893 \\
(3.313)^{* * *}\end{array}$ \\
\hline$\triangle$ RERVOL & $\begin{array}{c}0.001 \\
(1.865)^{*}\end{array}$ & $\begin{array}{c}0.001 \\
(1.825)^{*}\end{array}$ \\
\hline$\triangle \mathrm{OPEN}$ & $\begin{array}{l}18.060 \\
(0.560)\end{array}$ & $\begin{array}{l}19.722 \\
(1.07)\end{array}$ \\
\hline$\triangle \mathrm{RGDP}$ & $\begin{array}{c}0.028 \\
(1.912)^{*}\end{array}$ & $\begin{array}{l}-0.009 \\
(0.203)\end{array}$ \\
\hline $\mathrm{EC}$ & $\begin{array}{c}-0.205 \\
(4.139) * * *\end{array}$ & $\begin{array}{c}-0.324 \\
(4.592) * * *\end{array}$ \\
\hline $\operatorname{Adj} R^{2}$ & 0.216 & 0.241 \\
\hline DW & 1.55 & 1.77 \\
\hline $\mathrm{F}$ & $4.857 * * *$ & $4.823 * * *$ \\
\hline $\mathrm{N}$ & 155 & 109 \\
\hline
\end{tabular}

\section{AUTHOR INFORMATION}

Dharmendra Dhakal is an Associate Professor of Economics and Finance at Tennessee State University. He received his $\mathrm{PhD}$ in Economics from Southern Illinois University at Carbondale in 1991 and Post-Doctorate in Finance from Virginia Tech University in 2008. Dr. Dhakal teaches graduate as well undergraduate courses in both Finance and Economics. His primary research areas include international finance, international investment and macroeconomics. He works has been published in journals such as Applied Economics, Applied Economics Letters, Economics letters, International Journal of Social Economics among others.

Raja Nag is Professor of Finance at the School of Management, New York Institute of Technology. His research interests include SEOs, IPOs, REITs, asset valuation, and corporate finance. He has published papers in Real Estate Economics, Journal of Real Estate Finance \& Economics, Real Estate Finance, Journal of Real Estate Portfolio Management, Journal of Business and Economics Research, and Journal of Applied Business Research.

Gyan Pradhan is Professor and Chair of the Department of Economics at Eastern Kentucky University. He has taught at the University of New Hampshire, Washington University in St. Louis, and Westminster College, Missouri. At Westminster College, he was named the first Simon Chair in Business and the first Buckner Chair, and was awarded the President's Award for Excellence in Teaching. He also served as the Chair of the ABEMIS Department and Chair of the Social Sciences Division. His research in macroeconomics, international economics and development economics have appeared in many professional journals.

Kamal P. Upadhyaya is Professor and Chair of the Department of Economics and Finance at the University of New Haven. He has also held faculty positions at Salisbury University and Pennsylvania State University. He has extensively published in the area of international economics, macroeconomics, development economics and public choice. His recent works has been published in Eastern Economic Journal, Economic Inquiry, Economics Letters, Eastern Economic Journal, the Journal of Development Studies, Applied Economics, International Trade Journal, Public Choice, and the European Journal of Development Research. 


\section{REFERENCES}

1. Abel, A. 1983. "Optimal Investment Under Uncertainty,” American Economic Review, vol. 73, pp. 228233.

2. Abel, A. and J. Eberly. 1994. "A Unified Model of Investment Under Uncertainty,” American Economic Review, vol. 84, pp. 1369-1384.

3. Ajami, R. and R. BarNiv. 1984. "Utilizing Economic Indicators in Explaining Foreign Direct Investment in the U.S.," Management International Review, vol. 24, pp. 16-26.

4. Bernanke, B. 1983. "Irreversibility, Uncertainty and Cyclical Investment," Quarterly Journal of Economics, vol. 98, pp. 85-106.

5. Bhandari, R. and K. P. Upadhyaya. 2008. "Panel data evidence of the impact of exchange rate uncertainty on private investment in South-east Asia" Applied Economics, 1-5. iFirst, DOI:

$10.1080 / 00036840701564400$

6. Breitung, J. 2000. "Local Power of Some Unit Root Tests for Panel Data," in B. Baltagi (ed.), Advances in Econometrics, Vol. 15: Non Stationary Panels, Panel Cointegration, and Dynamic Panels, Amsterdam: JAI Press, pp. 161-178.

7. Caballero, R. 1991. "On the Sign of Investment-Uncertainty Relationship,” American Economic Review, vol. 81, pp. 279-288.

8. Chudnovsky, D., A. Lopez, and F. Porta. 1995. "New Foreign Direct Investment in Argentina: Privatization, the Domestic Market, and Regional Integration," In M.R. Agosin, (ed.), "Foreign Direct Investment in Latin America", Washington: Inter-American Development Bank.

9. Cushman, D. 1985. "Real Exchange Rate Risk Expectations, and Exchange Rate Risk During the Floating Period," Review of Economics and Statistics, vol. 67, pp. 302-307.

10. Cushman, D. 1988. "US Bilateral Trade Flows and Exchange Rate Risk During the Floating Period," Journal of International Economics, vol. 24, pp. 317-330.

11. Daniels, J. and C. Quigley. 1980. "Pull Factors for Direct Investment: A Cross Regional Comparison," Foreign Trade Review, vol. 15, pp. 263-288.

12. Darby, J., A. Hallett, J. Ireland, and L. Pisciltelli. 1999. "The Impact of Exchange Rate Uncertainty on the Level of Investment,” Economic Journal, vol. 109, pp. C55-C67.

13. Dixit, A. and R. Pindyck. 1994. Investment Under Uncertainty, Princeton, NJ: Princeton University Press.

14. Easterly, W., R. Islam, and J. Stiglitz. 2000. "Explaining Growth Volatility" in Annual World Bank Conference on Development Economics 2000, Oxford University Press.

15. Engle, R. and C. Granger. 1987. "Cointegration and Error Correction: Representation, Estimation, and Testing," Econometrica, vol. 55, pp. 251-76.

16. Froot, K. and J. Stein. 1991. "Exchange Rates and Foreign Direct Investment: An Imperfect Capital Markets Approach," Quarterly Journal of Economics, vol. 106, pp. 1191-1217.

17. Goldberg, L. 1993. "Exchange Rates and Investment in the United States Industry," Review of Economics and Statistics, vol. 75, pp. 575-588.

18. Goldberg, L. and C. Kolstad. 1995. "FDI, Exchange Rate Variability and Demand Uncertainty," International Economic Review, vol. 36, pp. 855-873.

19. Grosse, R. and L. Trevino. 1996. "Foreign Direct Investment in the United States: An Analysis by Country of Origin," Journal of International Business Studies, vol. 27, pp. 139-155.

20. Hartman, R. 1972. "The Effects of Price and Cost Uncertainty on Investment," Journal of Economic Theory, vol. 5, pp. 258-266.

21. Im, K., M. Pesaran, and Y. Shin. 2003. "Testing for Unit Roots in Heterogeneous Panels," Journal of Econometrics, vol. 115, pp. 53-74.

22. Klein, M. and Rosengren, E. 1994. "The Real Exchange Rate and Foreign Direct Investment in the United States: Relative Wealth versus Relative Wage Effects," Journal of International Economics, vol. 36, pp. 373-389.

23. Lee, J. and K. Shin. 2000. "The Role of Variable Input in the Relationship between Investment and Uncertainty," American Economic Review, vol. 90, pp. 667-680.

24. Leiderman, L. and A. Thorne. 1996. "The 1994 Mexican Crisis and its Aftermath: What are the Main Lessons?" In Guillermo A. Calvo, Morris Goldstein, and Eduard Hochreiter, (eds.), "Private Capital Flows to Emerging Markets after Mexican Crisis”, Washington: Institute for International Economics. 
25. Levin, A., C. Lin, and C. Chu. 2002. "Unit Root Test in Panel Data: Asymptotic and Finite Sample Properties," Journal of Econometrics, vol. 108, pp. 1-24.

26. Pedroni, P. 2004. "Panel Cointegration: Asymptotic and Finite Sample Properties of Pooled Time Series Tests with an Application to the Purchasing Power Parity Hypothesis," Econometric Theory, 20, pp. 597325.

27. Pedroni, P. 1999. "Critical Values for Cointegration Tests in Heterogeneous Panels with Multiple Regressors," Oxford Bulletin of Economics and Statistics, 61, 4, pp. 653-670.

28. Pradhan, G., Z. Schuster, and K. Upadhyaya. 2004. "Exchange Rate Uncertainty and the Level of Investment in Selected South-East Asian Countries," Applied Economics, vol. 36, pp. 2161-2165.

29. Root, F. and A. Ahmad. 1979. "Empirical Determinants of Manufacturing Direct Investment in Developing Countries," Economic Development and Cultural Change, vol. 27, pp. 751-767.

30. Roy, S. and J. Viaene. 1998. "On Strategic Vertical Foreign Investment," Journal of International Economics, vol. 46,2, pp. 253-279.

31. Serven, L. 2003. "Real-Exchange Rate Uncertainty and Private Investment in LDCs," Review of Economics and Statistics, vol. 85, pp. 212-218.

32. Sung, H. and H. Lapan. 2000. "FDI and Exchange Rate Uncertainty," International Economic Review, vol. 41, pp. 411-423.

33. Trevino, L., J. Daniels, H. Arbelaez, and K. Upadhyaya. 2002. "Market Reform and Foreign Direct Investment in Latin America: Evidence from an Error Correction Model," The International Trade Journal, vol. XVI, no. 4, pp. 367-392.

34. Tuman, J. and C. Emmert. 1999. "Explaining Japanese Foreign Direct Investment in Latin America," Social Science Quarterly, vol. 80, pp. 539-541.

35. Zeira, J. 1990. "Cost Uncertainty and the Rate of Investment," Journal of Economic Dynamics and Control, vol. 14, pp. 53-63. 